\title{
Applicability of an Integrated Moving Sponge Biocarrier-Osmotic Membrane Bioreactor MD System for Saline Wastewater Treatment Using Highly Salt- Tolerant Microorganisms
}

Nguyen Cong Nguyen ${ }^{\mathrm{a}, \mathrm{c}}$, Shiao-Shing Chen ${ }^{\mathrm{a}^{*}}$, Hau Thi Nguyen ${ }^{\mathrm{a}, \mathrm{c}}$, Ying-Hsuan Chen ${ }^{\mathrm{a}}$, Huu Hao Ngo $^{b^{*}}$, Wenshan Guo ${ }^{b}$, Saikat Sinha Ray ${ }^{\mathrm{a}}$, Hau-Ming Chang ${ }^{\mathrm{a}}$, Quang Huy Le ${ }^{\mathrm{c}}$

${ }^{a}$ Institute of Environmental Engineering and Management, National Taipei University of Technology, No.1, Sec. 3, Chung -Hsiao E. Rd, Taipei 106, Taiwan, ROC

${ }^{b}$ School of Civil and Environmental Engineering, Faculty of Engineering and Information Technology, University of Technology Sydney, Broadway, NSW2007, Australia ${ }^{c}$ Faculty of Environment and Natural Resources, DaLat University, Vietnam

\section{*Corresponding authors:}

E-mail address: f10919@ntut.edu.tw (Shiao-Shing Chen)

E-mail address: h.ngo@uts.edu.au (Huu Hao Ngo)

\section{ABSTRACT}

Osmotic membrane bioreactors (OsMBRs) are a recent breakthrough technology designed to treat wastewater. Nevertheless, their application in high-salinity wastewater treatment is not widespread because of the effects of saline conditions on microbial community activity. In response, this study developed an integrated sponge biocarrier-OsMBR system using highly salttolerant microorganisms for treating saline wastewater. Results showed that the sponge biocarrier-OsMBR obtained an average water flux of $2 \mathrm{~L} / \mathrm{m}^{2} \mathrm{~h}$ during a 92-day operation when 1 $\mathrm{M} \mathrm{MgCl}_{2}$ was used as the draw solution. The efficiency in removing dissolved organic compounds from the proposed system was more than $99 \%$, and nutrient rejection was close to $100 \%$, indicating excellent performance in simultaneous nitrification and denitrification processes in the biofilm layer on the carriers. Moreover, salt-tolerant microorganisms in the sponge biocarrier-OsMBR system worked efficiently in salt concentrations of $2.4 \%$. A polytetrafluoroethylene MD membrane (pores $=0.45 \mu \mathrm{m}$ ) served to regenerate the diluted draw solution in the closed-loop system and produce high-quality water. The moving sponge biocarrier-OsMBR/MD hybrid system demonstrated its potential to treat salinity wastewater treatment, with $100 \%$ nutrient removal and $99.9 \%$ conductivity rejection. 


\section{KEYWORDS}

Osmotic membrane bioreactor, forward osmosis, draw solution, moving sponge biocarrier, salinity wastewater, salt-tolerant microorganisms

\section{Introduction}

Saline wastewater containing high amounts of inorganic salt typically originates from industrial companies, such as seafood processing and vegetable canning companies. In particular, the seafood processing sector produces large volumes of saline wastewater with a high nutrient and organic concentration, and converts $95 \%$ of the water it consumes into polluted wastewater. Several methods, for instance biological and physico-chemical systems can be employed to treat saline effluents; however, physico-chemical techniques use large amounts of energy, and their start-up and operating costs are high. Therefore, saline wastewater is mostly treated through biological processes employing large amounts of microorganisms [1]. Nevertheless, microorganism activities are often compromised by a high saline concentration, causing low organic and nutrient removal and easy bulking of the activated sludge [2].

Normal microorganisms in biological treatment plants do not tolerate high-salt conditions because a high salt content (TDS $>10 \mathrm{~g} / \mathrm{L}$ ) in wastewater can trigger an outward flow of intracellular water and cell dehydration, leading to the loss of cell activity $[2,3]$. This presents a substantial obstacle for traditional biological processes in high-salinity wastewater treatments [2]. Although several specific biological processes (e.g., attached growth, rotating biological disc, sequencing batch reactor) and membrane bioreactors have been designed for saline wastewater, their rejection efficiencies are low in saline environments [4-6]. Kincannon and Gaudy [7] determined that BOD removal efficiency decreased to $30 \%$ when adding $30 \mathrm{~g} / \mathrm{L} \mathrm{NaCl}$ solution to freshwater sludge, and according to Dinçer and Kargi [8], phosphorus and nitrogen removal declined to $62 \%$ and $20 \%$, respectively, when the bioreactor salt concentration was $5 \%$ $\mathrm{NaCl}$. Moreover, membrane fouling in the membrane bioreactor (MBR) system was more severe because both extracellular polymeric substances and soluble microbial products were released under high-salinity stress conditions [9].

Researchers have investigated an innovative MBR with the potential to treat wastewater, the osmotic MBR (OsMBR) [10, 11]. The OsMBR is an ideal multi-barrier technology, combining a forward osmosis (FO) membrane and biological process that can be used for direct potable and indirect reuse applications [12-15]. The OsMBR draws permeate water through osmosis from mixed liquids, or through an FO membrane to a draw solution, and offers several valuable benefits, including low energy consumption, low fouling propensity, and high contaminant rejection $[11,13,16-18]$. Consequently, the OsMBR is considered to be a promising technology 
for wastewater treatment and water reuse [12]. However, high-salinity wastewater remains a large technical challenge for OsMBR systems because it affects biological process treatment, and subsequently causes FO membrane fouling during long-term operation and reduces nutrient removal. In response, this study developed an integrated moving sponge biocarrier-OsMBR system for high-salinity wastewater treatment that uses highly salt-tolerant microorganisms. This study investigated the effect of a high saline condition on dissolved organic carbon (DOC), nutrient removal, and water flux by using $1 \mathrm{M} \mathrm{MgCl}_{2}$ as a draw solution. Additionally, the diluted $\mathrm{MgCl}_{2}$ draw solution was regenerated utilizing a polytetrafluoroethylene (PTFE) MD membrane to separate it from the product water.

\section{Materials and Methods}

\subsection{Materials and Membranes}

$\mathrm{MgCl}_{2}$ (purity of 99\%) was purchased from Imperial Chemical Corp., Taiwan, and the highly salt-tolerant microorganisms were supplied by the Soy Sauce Wastewater Treatment Plant in southwest Taiwan. The cellulose triacetate nonwoven support (CTA-NW) FO membrane was obtained from Hydration Technology Innovations (OsMem ${ }^{\text {тм }}$ CTA Membrane 130806, Albany, OR, USA), whereas the PTFE MD membrane (pore size $=0.45 \mu \mathrm{m}$ ) was supplied by Ray-E Creative Co., Ltd., in Taiwan; the characteristics of both the MD and FO membranes are detailed in Table 1. The contact angle of the MD and FO membranes was measured using a CAM 100 (Opto-Mechatronics P Ltd., India). The thickness and mean pore size of the FO and MD membranes were recorded based on references [19-21].

Table 1. Characteristics of the MD and FO membranes

\begin{tabular}{lllll}
\hline Membrane & Thickness & $\begin{array}{l}\text { Mean pore } \\
\text { size }\end{array}$ & Contact angle ${ }^{\circ}$ & $\begin{array}{l}\text { Effective area per } \\
\text { module }\end{array}$ \\
\hline PTFE MD & $160 \mu \mathrm{m}$ & $0.45 \mu \mathrm{m}$ & $118^{\circ}$ & $100 \mathrm{~cm}^{2}$ \\
\hline CTA-NW FO & $50 \mu \mathrm{m}$ & $0.37 \mathrm{~nm}$ & $66^{\circ}$ & $130 \mathrm{~cm}^{2}$ \\
\hline
\end{tabular}

\subsection{Feed and Draw Solutions}

Synthetic high-salinity wastewater served as the inoculum for the sponge carriers, and as the feed solution for the sponge biocarrier-OsMBR/MD system. It had a salt content of $1.7 \% \mathrm{NaCl}$ (corresponding to an osmotic pressure of $11.5 \mathrm{bar}$ ), $300 \pm 3 \mathrm{mg} / \mathrm{L} \mathrm{DOC}, 36 \pm 2 \mathrm{mg} / \mathrm{L} \mathrm{NH}_{4}{ }^{+}-\mathrm{N}$, and $22 \pm 2 \mathrm{mg} / \mathrm{L} \mathrm{PO}_{4}{ }^{3-}-\mathrm{P}$. The draw solution was subsequently prepared using $1 \mathrm{M} \mathrm{MgCl}_{2}$ in a draw solution tank. 


\subsection{Sponge Biocarrier-OsMBR/MD System Structure and Operation}

The laboratory-scale sponge biocarrier-OsMBR/MD hybrid system comprised a feed tank, an aerobic bioreactor with a moving sponge biocarrier, a submerged FO membrane tube, and an MD unit, as depicted in Figure 1. Prior to operating the sponge biocarrier-OsMBR, highly salttolerant microorganisms were seeded into the bioreactor-contained sponge carriers (cubic shape $\left.=1 \mathrm{~cm}^{3}\right) ;$ a $40 \%$ filling rate by volume was applied to acclimatize the biofilm carriers until many microorganisms became attached to the sponge (Figure 2), and the removal efficiency of $\mathrm{NH}_{4}^{+}-$ $\mathrm{N}, \mathrm{PO}_{4}{ }^{3-}-\mathrm{P}$, and DOC was stable. After 75 days of acclimatization, the quantity of biomass attached on media was $0.86 \mathrm{~g} / \mathrm{g}$ of sponge.

In the OsMBR a CTA-NW flat sheet membrane was wrapped and formed into a tube. The FO membrane tube had an effective area of $130 \mathrm{~cm}^{2}$ and was vertically immersed in the bioreactor tank with the active layer of the membrane facing the feed solution. At the bottom of the bioreactor, air diffusers were installed to reduce membrane fouling and the movement of sponge. In the sponge biocarrier-OsMBR system, synthetic saline wastewater (1.7\%) was continuously pumped into the bioreactor tank from a feed reservoir $(6 \mathrm{~L})$, with the liquid level in the bioreactor tank maintained by connecting an overflow pipe to the feed tank. The $\mathrm{MgCl}_{2}$ draw solution was pumped into the FO membrane tube, which caused water from the feed solution to permeate the membrane and dilute the draw solution. The feed reservoir was placed on a digital scale (BW12KH, Shimadzu, Japan), and the water flux was calculated according to changes in the feed tank weight. The theoretical water flux $\left(\mathrm{J}_{\mathrm{w}}\right)$ through the FO membrane is a product of the osmotic pressure gradient $(\pi)$ and the membrane permeability coefficient $\left(\mathrm{A}_{\mathrm{W}}\right)[22]$ :

$\mathrm{J}_{\mathrm{w}}=\mathrm{A}_{\mathrm{w}}\left(\pi_{\text {Draw solution }}-\pi_{\text {Feed solution }}\right)$

The experimental water flux $\mathrm{J}_{\mathrm{w}}\left(\mathrm{L} / \mathrm{m}^{2} \mathrm{~h}\right)$ of the FO membrane was calculated by measuring the change in the feed tank weight over time:

$J_{w}=\frac{\Delta V}{A \Delta t}$

Salt accumulation in the bioreactor was calculated by monitoring the conductivity of mixed liquid in the bioreactor with a conductivity meter (Oakton Instruments, USA). Temperature fluctuations in the draw solution during the experiment ranged from $26{ }^{\circ} \mathrm{C}$ to $29{ }^{\circ} \mathrm{C}$, and samples were collected from the bioreactor and draw solution reservoir to measure the DOC, $\mathrm{NH}_{4}{ }^{+}-\mathrm{N}$, and $\mathrm{PO}_{4}{ }^{3-}$-P. During sponge biocarrier-OsMBR operation, $200 \mathrm{~mL}$ of mixed liquid from the bioreactor was withdrawn every $24 \mathrm{~h}$ and settled for $30 \mathrm{~min}$. Clarified supernatants were then discarded and water from the mixed liquid was sampled for analysis. 


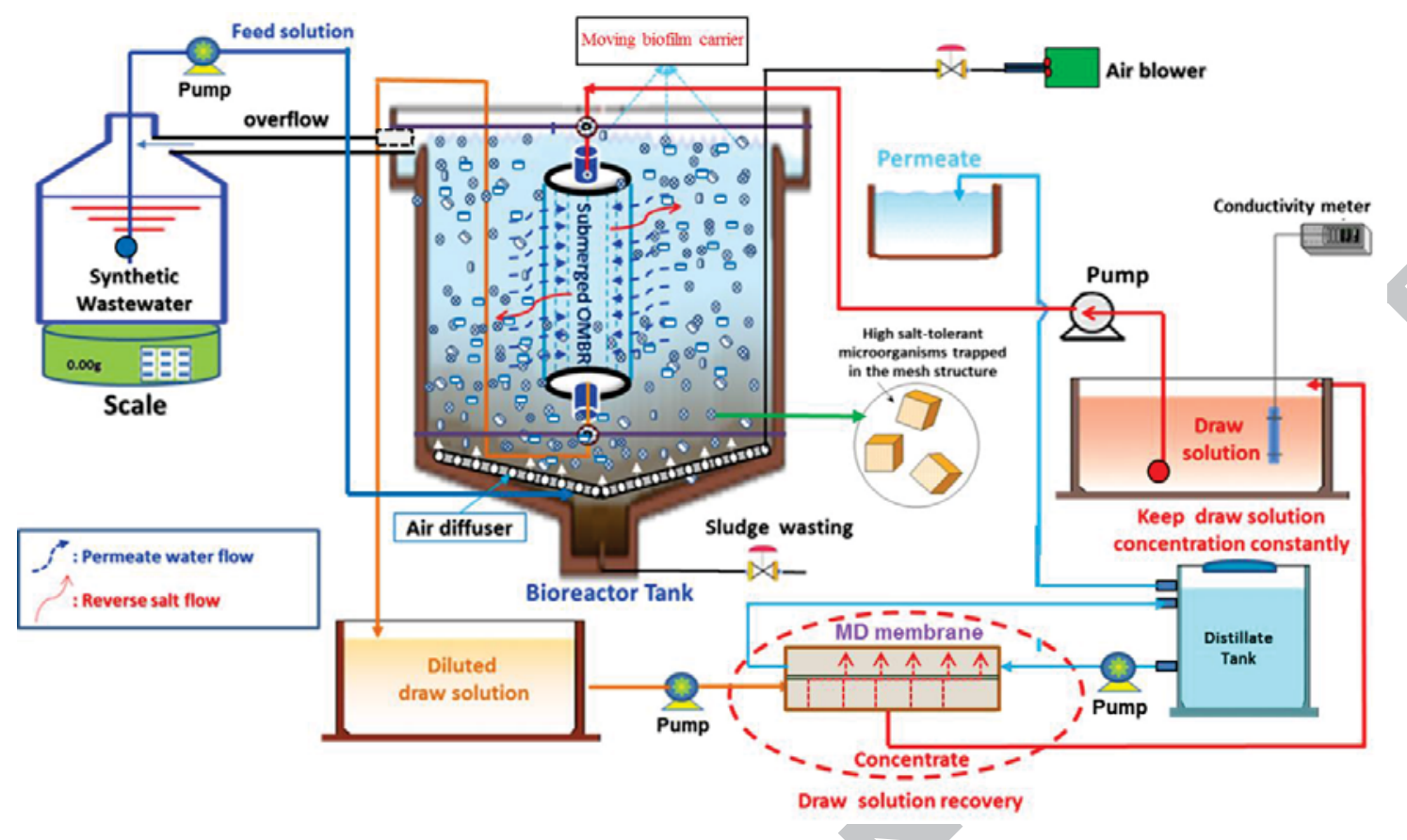

Figure 1. Schematic of the laboratory-scale sponge biocarrier-OsMBR/MD system.

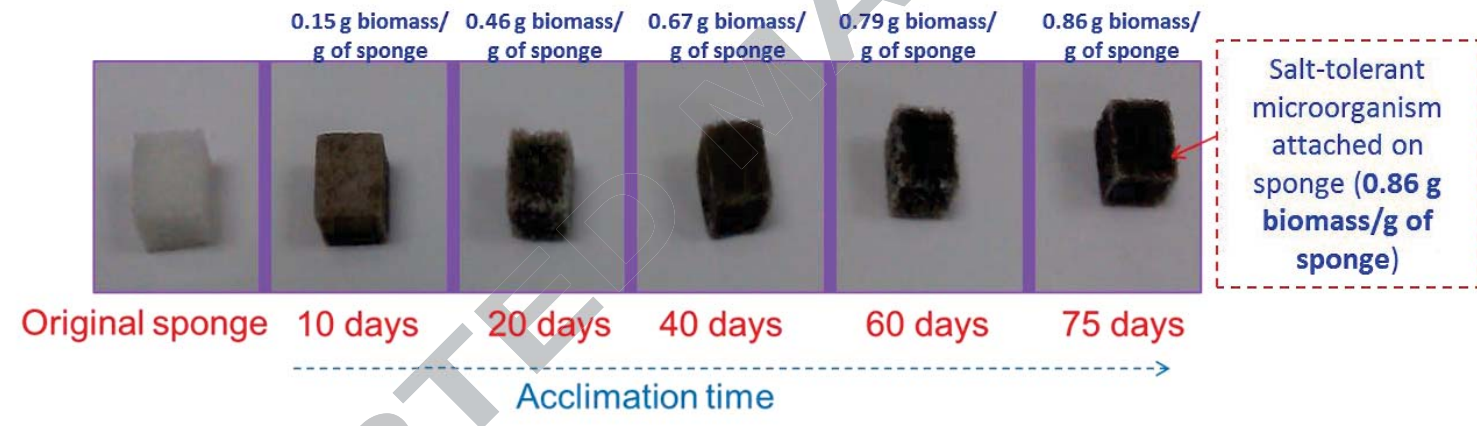

Figure 2. Acclimation of the sponge in the bioreactor with time using salt-tolerant microorganisms.

Subsequently, a laboratory-scale cross-flow MD membrane cell was applied to regenerate the draw solution to its initial concentration (Figure 3). The cell comprised acrylic and consisted of two semi-cells, each with a flow channel measuring $10 \mathrm{~cm}$ long, $10 \mathrm{~cm}$ wide, and $0.3 \mathrm{~cm}$ deep. The feed and distillate solutions were continuously circulated using peristaltic pumps (Baoding Longer Precision Pump Co., Ltd., Taiwan) with a flow rate of $1.5 \mathrm{~L} / \mathrm{min}$. The diluted draw solution (controlled temperature $=55 \pm 1{ }^{\circ} \mathrm{C}$ ) was pumped from a feed reservoir to the MD membrane cell and then returned to the reservoir. The initial distillate stream was deionized water $\left(20 \pm 1{ }^{\circ} \mathrm{C}\right)$, and circulated from a $1.5 \mathrm{~L}$ reservoir through the distillate membrane semicell before returning to the reservoir. Excess permeate water overflowed into a container, which was continually recorded on an analytical balance to calculate the water flux of MD. To ensure experimental reproducibility, three new MD membranes were used to repeat these experiments. 


\section{ACCEPTED MANUSCRIPT}

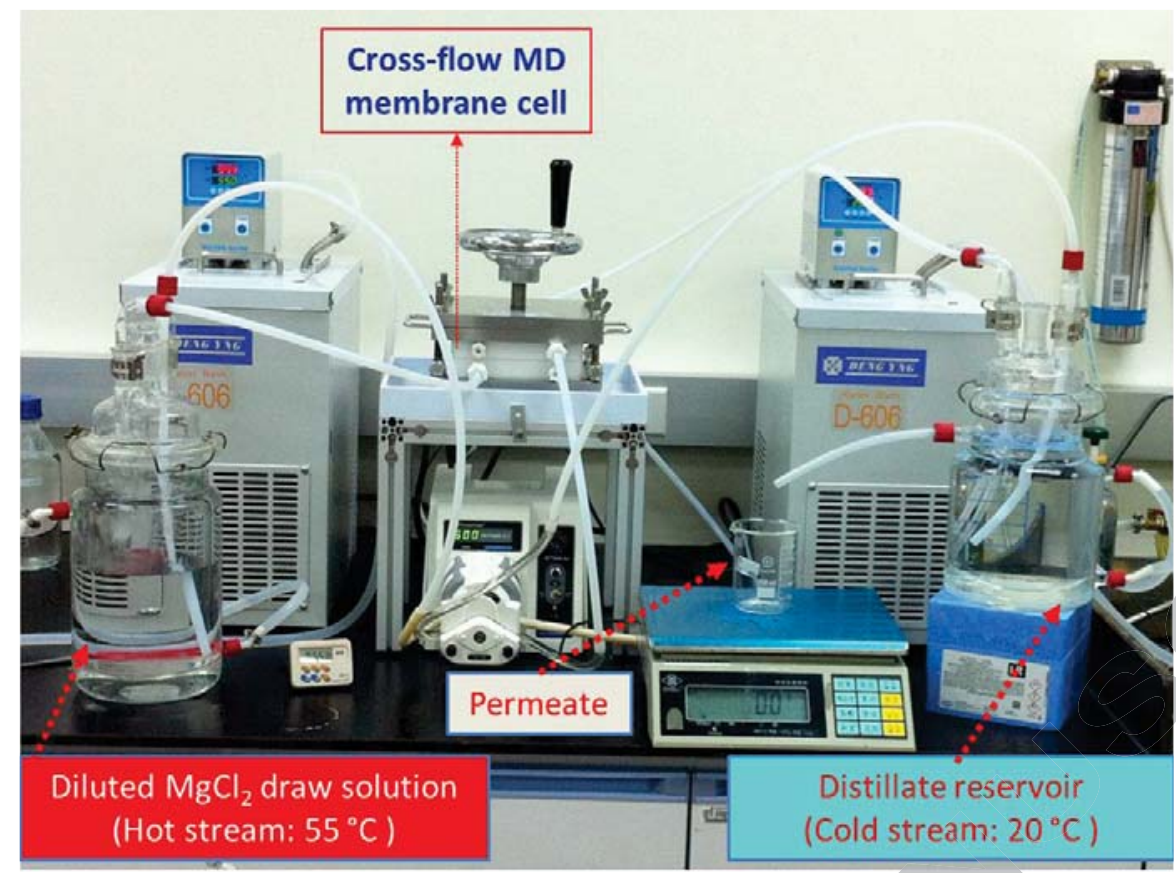

Figure 3. Laboratory-scale MD system for draw solution recovery.

\subsection{Analytical Methods}

The electrical conductivity and $\mathrm{pH}$ of the MD distillate, feed, and draw solution were measured using a conductivity/pH probe (Sension156, Hach, China). All DOC samples were initially filtered using $0.45 \mu \mathrm{m}$ filter paper and then verified using a total organic carbon analyzer (Aurora 1010C, O.I. Analytical Corporation, USA). The dissolved oxygen (DO) in the sponge biocarrier-OsMBR system bioreactor was measured daily using a DO meter (OM-51E, Horiba Ltd., Japan). Concentrations of $\mathrm{PO}_{4}{ }^{3-}-\mathrm{P}$ and $\mathrm{NH}_{4}{ }^{+}-\mathrm{N}$ were examined using an ultraviolet-visible spectrophotometer (DR-4000, Hach, Japan), and viscosity was determined using the Vibro Viscometer (AD Company, Japan).

The draw solution osmolality was measured using an osmometer (Model 3320, Advanced Instruments, Inc., USA). It was then converted into osmotic pressure according to the Morse equation, as follows:

$\pi=\left(\sum \phi \cap C\right) R T$

where $R$ is the universal gas constant, $(\Sigma \phi n C)$ represents total osmolality, and $T$ is the absolute temperature.

\section{Results and Discussion}

\subsection{Nutrient and Organic Removal in Sponge Biocarrier-OsMBR System}

Removal efficiencies during the sponge biocarrier-OsMBR's operation were calculated using concentrations from the feed and diluted draw solutions, and as depicted in Figure 4a, the system removed organic matter efficiently. Initially (first 20 days), DOC removal was nearly 100\%; after 20 days, the removal efficiency decreased slightly because salinity buildup in the 
bioreactor affected biological activity. Notably, the average DOC removal efficiency still reached $99.1 \%$ (Figure $4 \mathrm{a}$ ), because of the very small $(0.37 \mathrm{~nm})$ mean pore size of the CTA-NW FO membrane. Thus, almost all organic contaminants (i.e., DOC) remained in the bioreactor tank instead of penetrating the membrane. Moreoever, a large biomass of microorganisms attached to the sponge could biodegrade these organic compounds, thereby enhancing DOC removal. Figure $4 \mathrm{~b}$ shows that the sponge biocarrier-OsMBR system removed approximately $98.9 \%$ of $\mathrm{PO}_{4}{ }^{3-}-\mathrm{P}$ in treating high-salinity wastewater. The possible reasons for the high $\mathrm{PO}_{4}{ }^{3-}-\mathrm{P}$ removal percentage include: (1) the steric effect; and (2) electrostatic repulsion of the FO membrane. During the system's operation, the mixed liquid $\mathrm{pH}$ was set between 6.5 and 7.0; at $\mathrm{pH}>6$, the CTA-NW FO membrane was negatively charged [23] and repelled negative $\mathrm{PO}_{4}{ }^{3-}$ ions, preventing $\mathrm{PO}_{4}{ }^{3-}-\mathrm{P}$ from crossing through the membrane. Moreover, since only a negligible amount of biomass (MLSS of $350 \mathrm{mg} / \mathrm{L}$ in bioreactor) was detached from the sponge during the 92-day sponge biocarrier-OsMBR operation, the presence of phosphorus-accumulating organisms in forms of attached growth on sponge carriers in the aerobic and anoxic biofilms, leading to increased phosphorus removal [24-26].

A key benefit of adding a sponge biocarrier into the OsMBR system is that aerobic and anoxic microzones were formed at both the outer layer and inner layer of the biofilm [27]. Thus, simultaneous nitrification and denitrification processes occurred in a single reactor, which appreciably enhanced nutrient removal (Figure 5). The average removal efficiency of $\mathrm{NH}_{4}{ }^{+}-\mathrm{N}$ was $99.5 \%$, and the $\mathrm{NH}_{4}{ }^{+}-\mathrm{N}$ concentration in the draw solution was very low $(<0.45 \mathrm{mg} / \mathrm{L})$. In addition, $\mathrm{NO}_{2}{ }^{-} \mathrm{N}$ and $\mathrm{NO}_{3}{ }^{-} \mathrm{N}$ concentrations in the bioreactor tank were less than $6.5 \mathrm{mg} / \mathrm{L}$ during the 92-day operation (Fig. 5b and c), which explained the occurrence of efficient denitrification in the anoxic and anaerobic zones of the attached biofilm in the sponge. As a result, the average $\mathrm{NO}_{2}{ }^{-}-\mathrm{N}$ and $\mathrm{NO}_{3}{ }^{-} \mathrm{N}$ concentrations in the draw solution were relatively low (0.91 and $1.96 \mathrm{mg} / \mathrm{L}$ for $\mathrm{NO}_{2}{ }^{-}-\mathrm{N}$ and $\mathrm{NO}_{3}{ }^{-}-\mathrm{N}$, respectively).
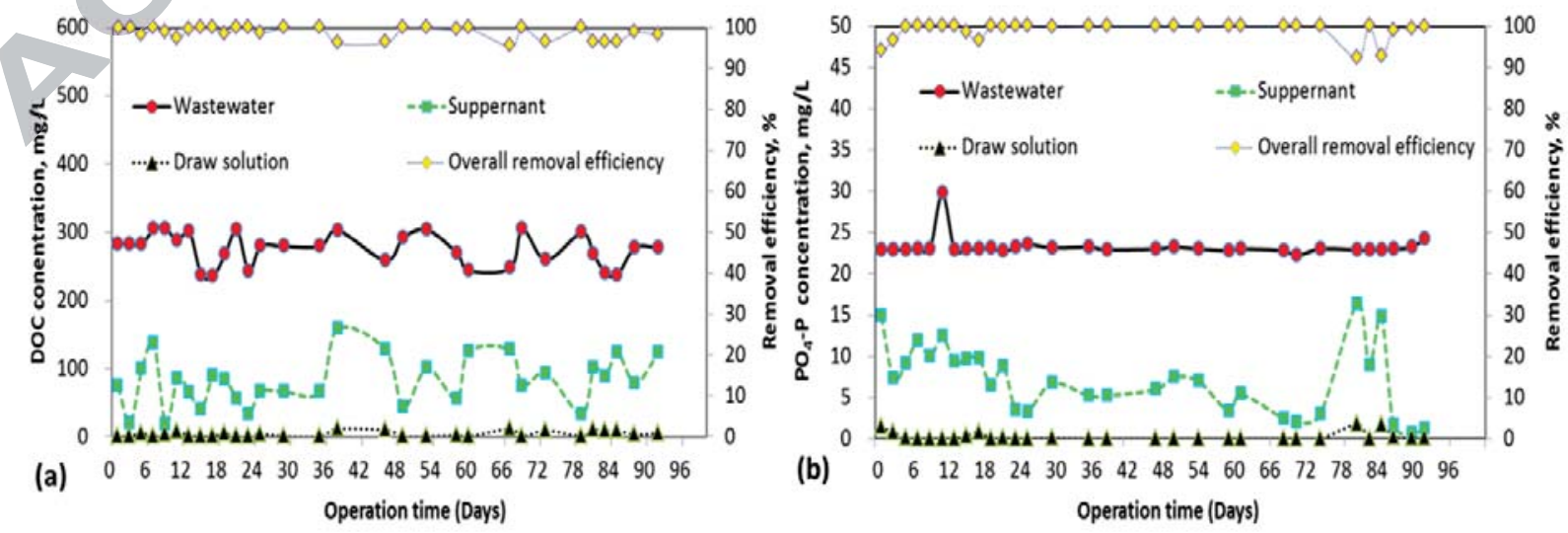
Figure 4. Removal of (a) DOC, (b) $\mathrm{PO}_{4}{ }^{3-}-\mathrm{P}$ during moving sponge biocarrier-OsMBR operation. Operating conditions: draw solution $=\mathrm{MgCl}_{2}$, draw solution osmotic pressure $=75$ bar; feed solution $=$ synthetic high-salinity wastewater $(17 \mathrm{~g} \mathrm{NaCl} / \mathrm{L})$; flow rate of draw solution $=500$ $\mathrm{mL} / \mathrm{min}$; membrane orientation = active layer facing the feed solution.
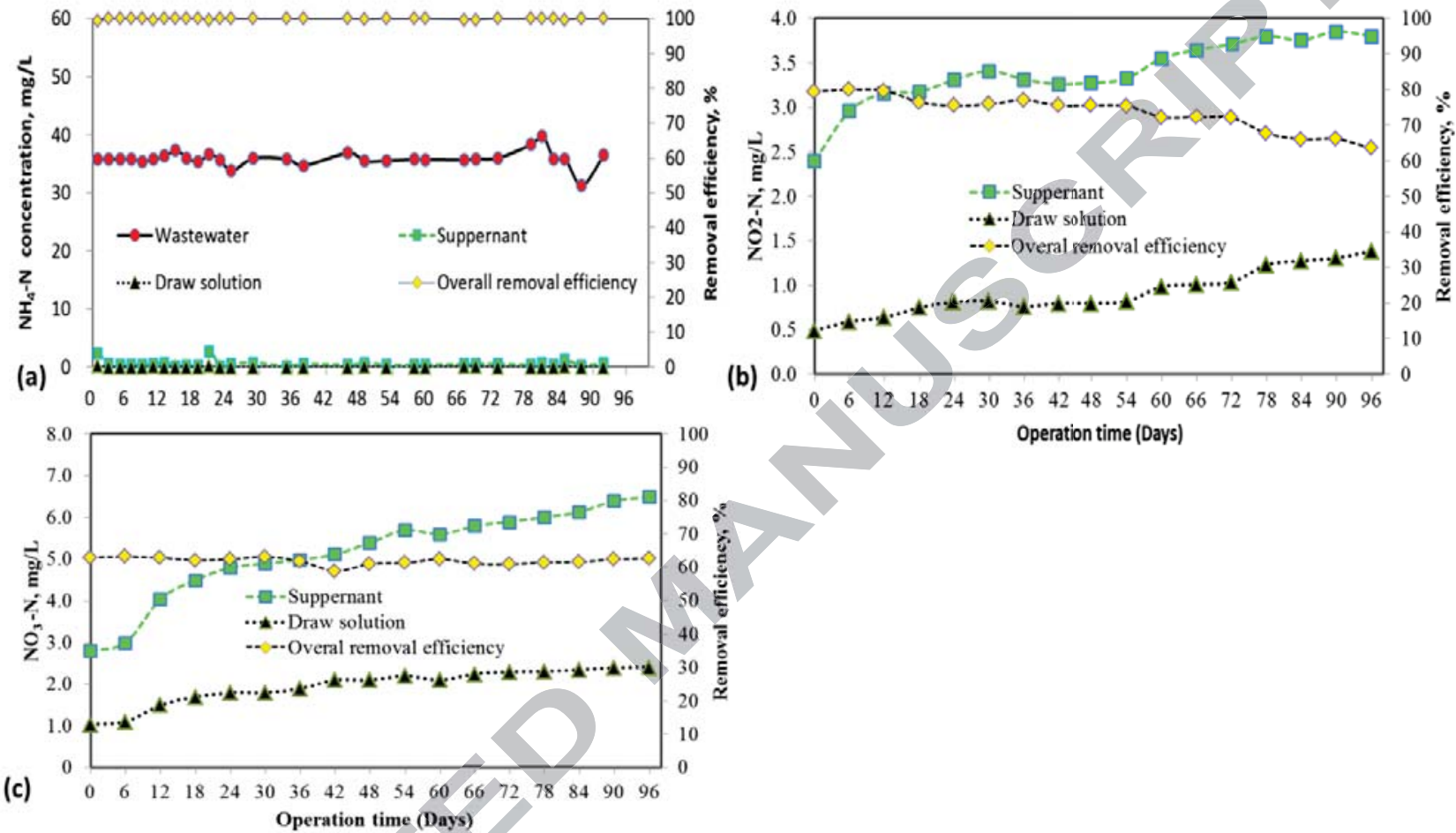

Operation time (Days)

Figure 5. Removal of (a) $\mathrm{NH}_{4}{ }^{+}-\mathrm{N}$, (b) $\mathrm{NO}_{2}{ }^{-}-\mathrm{N}$ and (c) $\mathrm{NO}_{3}{ }^{-}-\mathrm{N}$ during moving sponge biocarrierOsMBR operation. Operating conditions: draw solution $=\mathrm{MgCl}_{2}$, draw solution osmotic pressure $=75$ bar, feed solution $=$ synthetic high-salinity wastewater $(17 \mathrm{~g} \mathrm{NaCl} / \mathrm{L})$; flow rate of draw solution $=500 \mathrm{~mL} / \mathrm{min}$; membrane orientation $=$ active layer facing the feed solution .

\subsection{Variation of Water Flux and Salt Accumulation in Sponge Biocarrier-OsMBR}

Figure 6a shows water flux as a function of time during the testing of the moving sponge biocarrier-OsMBR system, using $1 \mathrm{M} \mathrm{MgCl}_{2}$ as the draw solution and high-salinity wastewater as the feed solution. The water flux gradually declined from 2.27 to $1.78 \mathrm{~L} / \mathrm{m}^{2} \mathrm{~h}$, attributable to both salinity buildup in the bioreactor and membrane fouling. During sponge biocarrier-OsMBR operation, the reverse salt flux of the $\mathrm{MgCl}_{2}$ solution to the bioreactor markedly increased salinity in the bioreactor, resulting in a decreased driving force across the FO membrane. Both Nguyen et al. [28] and Li et al. [29] have demonstrated that salinity buildup in the bioreactor is primarily responsible for the water flux decline.

Figure $6 \mathrm{~b}$ illustrates that most of the salt-tolerant microorganism biomasses are attached to the inside and outside of sponge biocarriers rather than the FO membrane, which reduced membrane 
fouling considerably. Moreover, a freely moving sponge in the bioreactor could remove foulants attached to the FO membrane tube, which was effectively designed in this study; the remaining foulants on the FO membrane could be easily eliminated by the hydraulic shear force generated by aeration [30]. Subsequently, no appreciable membrane fouling in the sponge biocarrierOsMBR occurred, and the increased salt concentration in the bioreactor over time substantially contributed to water flux decline. Changes in experiment temperatures (ranging from $26{ }^{\circ} \mathrm{C}$ to $29^{\circ} \mathrm{C}$ ) (Figure 6a) were also a reason for the fluctuating water flux during moving sponge biocarrier-OsMBR operation [31].

Figure 6c displays salt accumulation in the bioreactor over time. Within the first 40 days of operation, conductivity in the bioreactor gradually increased from 29.9 to $36.3 \mathrm{mS} / \mathrm{cm}$; a combination of salt rejection by the $\mathrm{FO}$ membrane and salt leakage from the $\mathrm{MgCl}_{2}$ draw solution produced an increasing mixed liquid conductivity in the bioreactor [32]. Subsequently, the mixed liquid conductivity became relatively stable at approximately $38 \mathrm{mS} / \mathrm{cm}$, as a result of the daily discharge of $200 \mathrm{~mL}$ of mixed liquid from the bioreactor. Nutrient and organic removal remained high, even as the salt concentration in the bioreactor reached $24 \mathrm{~g} / \mathrm{L}$, demonstrating that salt-tolerant microorganisms in a moving sponge biocarrier-OsMBR system continue to work efficiently in high-salinity conditions. 

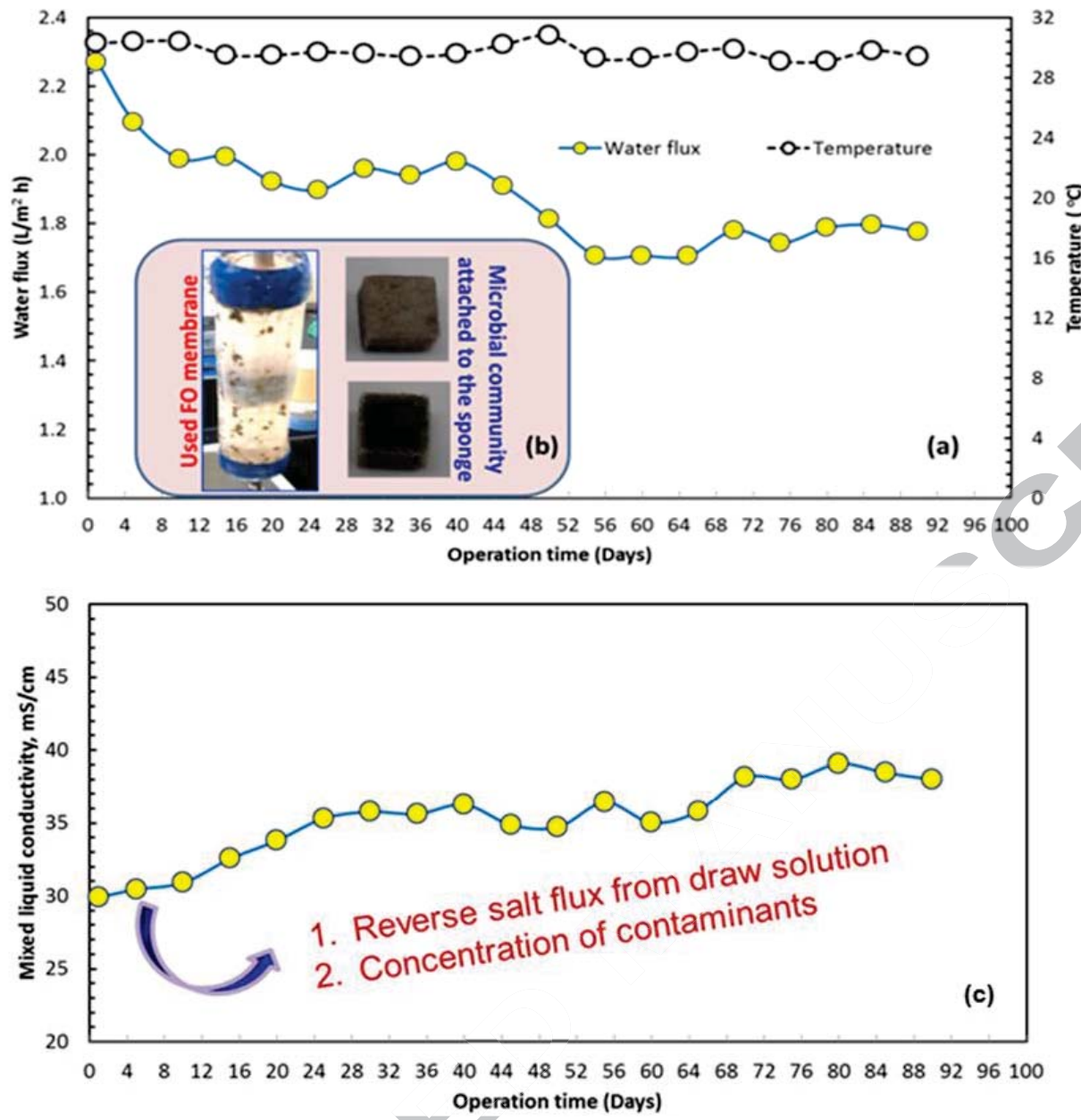

Figure 6. (a) Water flux of the moving sponge biocarrier-OsMBR system vs time; (b) Microbial community attached to the sponge carrier and FO membrane; (c) Variations of salt accumulation during sponge biocarrier-OsMBR operation. Operating conditions: draw solution $=\mathrm{MgCl}_{2}$; draw solution osmotic pressure $=75$ bar; feed solution $=$ synthetic high-salinity wastewater $(17 \mathrm{~g}$ $\mathrm{NaCl} / \mathrm{L}$ ); flow rate of draw solution $=500 \mathrm{~mL} / \mathrm{min}$; membrane orientation $=$ active layer facing the feed solution.

\subsection{Recovery of Diluted Draw Solution Using MD}

The submerged FO membrane transferred water from the mixed liquid into the draw solution through osmotic pressure; subsequently, the draw solution was diluted from $83 \mathrm{~g} / \mathrm{L}$ to $77 \mathrm{~g} / \mathrm{L}$ and was sent to an MD system for regeneration. Using a PTFE MD membrane (pore size $=0.45$ $\mu \mathrm{m})$, the draw solution was returned to its original concentration and continued producing highquality water. Figure 7 depicts the MD water flux achieving approximately 4.8 LMH during 180 $\mathrm{h}$ operation under a feed temperature of $55{ }^{\circ} \mathrm{C}$ and distillate temperature of $20{ }^{\circ} \mathrm{C}$. The MD water flux did not drastically change over time, even when the osmotic pressure of the feed solution gradually increased from 71 to 75 bar, indicating that MD does not depend on the osmotic pressure of the feed solution. This confirms research by Duong et al. [33] and Wang et 
al. [34], who have similarly observed that increases in water recovery or feed concentration do not affect MD water flux.

Additionally, a PTFE membrane with $0.45 \mu \mathrm{m}$ pores rejected almost all ions $(>99.9 \%)$ in the diluted draw solution during $180 \mathrm{~h}$ operation. The high salt rejection can be attributed to the MD process, whereby only water vapor is transported through the PTFE membrane pores while preventing the permeation of liquid water. As a result, dissolved solutes (i.e. inorganic salts that cannot be evaporated) can be completely rejected by MD [35]. The distillate conductivity also slightly increased over time because the TDS in feed and wetting membranes caused the conductivity of MD permeate water to increase. Notably, the quality of the water produced was still sufficiently high for beneficial reuse (distillate conductivity $<60 \mathrm{mg} / \mathrm{L}$ ). After $180 \mathrm{~h}$ operation, the feed solution $(\mathrm{TDS}=77 \mathrm{~g} / \mathrm{L})$ returned to its original concentration $(\mathrm{TDS}=83$ $\mathrm{g} / \mathrm{L}$ ), which enabled the draw solution to be reused in the sponge biocarrier-OsMBR system.

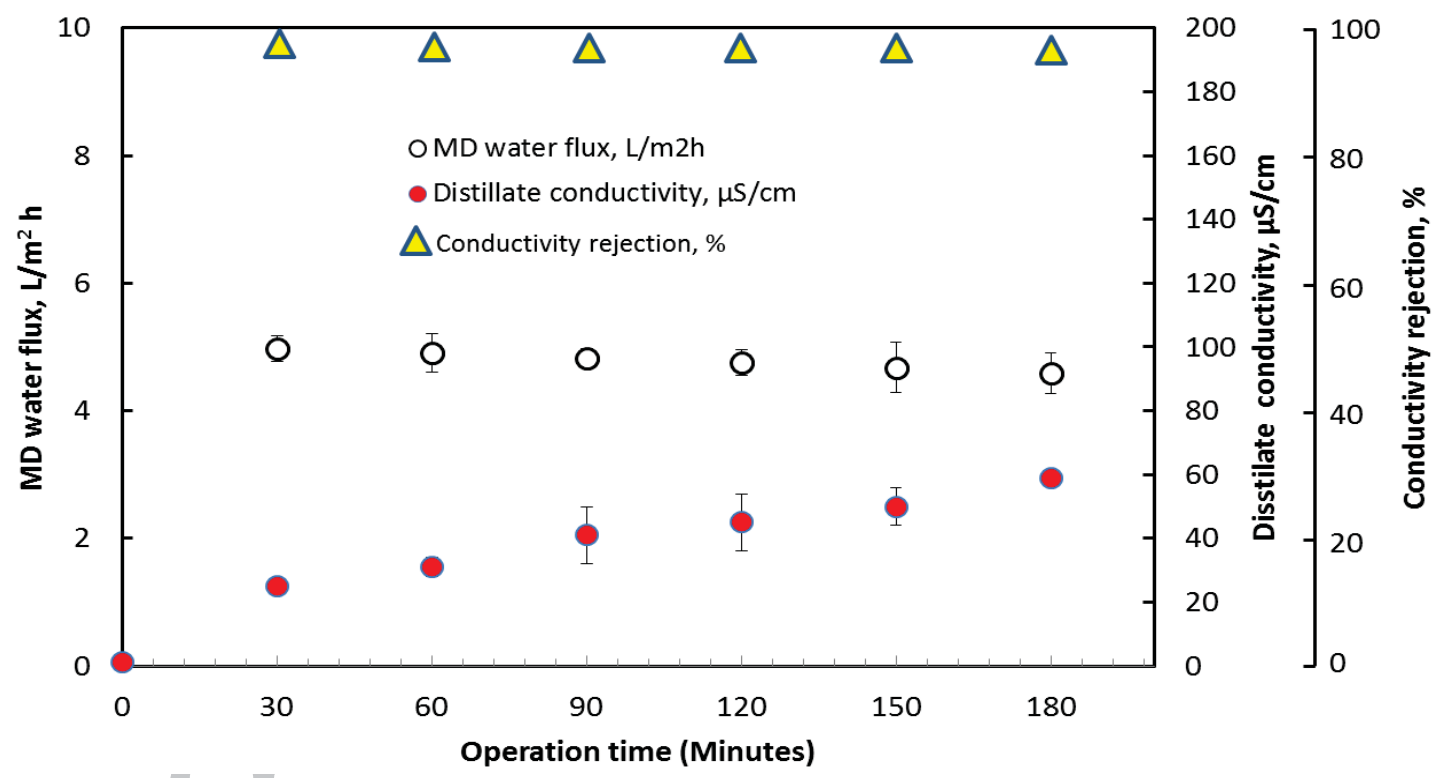

Figure 7. Water flux, salt rejection, and feed conductivity in the MD process as a function of time. Operating conditions: diluted $\mathrm{MgCl}_{2}$ draw solution as feed; $\mathrm{T}_{\text {feed }}=55^{\circ} \mathrm{C} ; \mathrm{T}_{\text {distillate }}=20{ }^{\circ} \mathrm{C}$; distillate flow rate $=1.5 \mathrm{~L} / \mathrm{min}$; PTFE MD membrane pore size $=0.45 \mu \mathrm{m}$. Error bars are based on the standard deviations of three replicate tests.

\section{Conclusions}

The moving sponge biocarrier-OsMBR/MD hybrid system was successfully applied to highsalinity wastewater by using salt-tolerant microorganisms that efficiently removed organic and nutrient compounds. Water flux decreased slightly due to salinity buildup in the bioreactor, and FO membrane fouling was minimal because the biomass of most salt-tolerant microorganisms was attached to the biocarriers rather than the FO membrane surface. This research also demonstrated that salt-tolerant microorganisms still work efficiently in a salt concentration of 
2.4\%, with removal efficiencies of DOC, $\mathrm{NH}_{4}{ }^{+}-\mathrm{N}$, and $\mathrm{PO}_{4}{ }^{3-}-\mathrm{P}$ at $99.1 \%, 99.5 \%$, and $98.9 \%$, respectively. Finally, the PTFE MD membrane was highly efficient at conductivity removal (99.9\%), with a final distillate conductivity of $60 \mu \mathrm{S} / \mathrm{cm}$.

\section{Acknowledgment}

This work was supported by Southern Taiwan Science Park and the Ministry of Science and Technology of the Republic of China under the grant number of 104-2221-E-027-004- MY3.

\section{References:}

[1] X. Zhang, J. Gao, F. Zhao, Y. Zhao, Z. Li, Characterization of a salt-tolerant bacterium Bacillus sp. from a membrane bioreactor for saline wastewater treatment, Journal of Environmental Sciences, 26 (2014) 1369-1374.

[2] T. Osaka, K. Shirotani, S. Yoshie, S. Tsuneda, Effects of carbon source on denitrification efficiency and microbial community structure in a saline wastewater treatment process, Water Research, 42 (2008) 3709-3718.

[3] M.S. Moussa, D.U. Sumanasekera, S.H. Ibrahim, H.J. Lubberding, C.M. Hooijmans, H.J. Gijzen, M.C.M. Van Loosdrecht, Long term effects of salt on activity, population structure and floc characteristics in enriched bacterial cultures of nitrifiers, Water Research, 40 (2006) 1377-1388.

[4] A. Uygur, Specific nutrient removal rates in saline wastewater treatment using sequencing batch reactor, Process Biochemistry, 41 (2006) 61-66.

[5] N.P. Dan, C. Visvanathan, B. Basu, Comparative evaluation of yeast and bacterial treatment of high salinity wastewater based on biokinetic coefficients, Bioresource Technology, 87 (2003) 51-56.

[6] A.R. Din Ãßer, F. Kargi, Performance of rotating biological disc system treating saline wastewater, Process Biochemistry, 36 (2001) 901-906.

[7] D.F. Kincannon, A.F. Gaudy, Response of biological waste treatment systems to changes in salt concentrations, Biotechnology and Bioengineering, 10 (1968) 483-496.

[8] A.R. DinÃ §er, F. Kargi, Salt inhibition kinetics in nitrification of synthetic saline wastewater, Enzyme and Microbial Technology, 28 (2001) 661-665.

[9] S.H. Park, B. Park, H.K. Shon, S. Kim, Modeling full-scale osmotic membrane bioreactor systems with high sludge retention and low salt concentration factor for wastewater reclamation, Bioresource Technology, 190 (2015) 508-515.

[10] E.R. Cornelissen, D. Harmsen, K.F. de Korte, C.J. Ruiken, J.-J. Qin, H. Oo, L.P. Wessels, Membrane fouling and process performance of forward osmosis membranes on activated sludge, Journal of Membrane Science, 319 (2008) 158-168.

[11] A. Achilli, T.Y. Cath, E.A. Marchand, A.E. Childress, The forward osmosis membrane bioreactor: A low fouling alternative to MBR processes, Desalination, 239 (2009) 10-21.

[12] A. Alturki, J. McDonald, S.J. Khan, F.I. Hai, W.E. Price, L.D. Nghiem, Performance of a novel osmotic membrane bioreactor (OMBR) system: Flux stability and removal of trace organics, Bioresource Technology, 113 (2012) 201-206. 
[13] M.S. Nawaz, G. Gadelha, S.J. Khan, N. Hankins, Microbial toxicity effects of reverse transported draw solute in the forward osmosis membrane bioreactor (FO-MBR), Journal of Membrane Science, 429 (2013) 323-329.

[14] N.C. Nguyen, S.-S. Chen, H.T. Nguyen, S.S. Ray, H.H. Ngo, W. Guo, P.-H. Lin, Innovative sponge-based moving bed-osmotic membrane bioreactor hybrid system using a new class of draw solution for municipal wastewater treatment, Water Research, 91 (2016) 305-313.

[15] N.C. Nguyen, S.-S. Chen, H.T. Nguyen, H.H. Ngo, W. Guo, C.W. Hao, P.--H. Lin, Applicability of a novel osmotic membrane bioreactor using a specific draw solution in wastewater treatment, Science of The Total Environment, 518-519 (2015) 586-594.

[16] W.C.L. Lay, Q. Zhang, J. Zhang, D. McDougald, C. Tang, R. Wang, Y. Liu, A.G. Fane, Study of integration of forward osmosis and biological process: Membrane performance under elevated salt environment, Desalination, 283 (2011) 123-130.

[17] G. Qiu, Y.P. Ting, Osmotic membrane bioreactor for wastewater treatment and the effect of salt accumulation on system performance and microbial community dynamics, Bioresource Technology, 150 (2013) 287-297.

[18] M.K. Yin Tang, H.Y. Ng, Impacts of different draw solutions on a novel anaerobic forward osmosis membrane bioreactor (AnFOMBR), Water Science and Technology, 69 (2014) 2036-2042.

[19] T.Y. Cath, A.E. Childress, M. Elimelech, Forward osmosis: Principles, applications, and recent developments, Journal of Membrane Science, 281 (2006) 70-87.

[20] F.-x. Kong, H.-w. Yang, Y.-q. Wu, X.-m. Wang, Y.F. Xie, Rejection of pharmaceuticals during forward osmosis and prediction by using the solutionâ€"diffusion model, Journal of Membrane Science, 476 (2014) 410-420.

[21] M. Xie, Nghiem, L. D.,Price, W. E.,Elimelech, M., Relating rejection of trace organic contaminants to membrane properties in forward osmosis: Measurements, modelling and implications, Water Research, 49 (2014) 265-274.

[22] N.C. Nguyen, S.-S. Chen, H.-Y. Yang, N.T. Hau, Application of forward osmosis on dewatering of high nutrient sludge, Bioresource Technology, 132 (2013) 224-229.

[23] J.L. Cartinella, T.Y. Cath, M.T. Flynn, G.C. Miller, K.W. Hunter, A.E. Childress, Removal of Natural Steroid Hormones from Wastewater Using Membrane Contactor Processes, Environmental Science \& Technology, 40 (2006) 7381-7386.

[24] H. MonclA $\tilde{A}^{\mathrm{s}}$, J. Sipma, G. Ferrero, I. Rodriguez-Roda, J. Comas, Biological nutrient removal in an MBR treating municipal wastewater with special focus on biological phosphorus removal, Bioresource Technology, 101 (2010) 3984-3991.

[25] W. Guo, H.-H. Ngo, F. Dharmawan, C.G. Palmer, Roles of polyurethane foam in aerobic moving and fixed bed bioreactors, Bioresource Technology, 101 (2010) 14351439.

[26] L.-1. Bao, D. Li, X.-k. Li, R.-x. Huang, J. Zhang, Y. Lv, G.-q. Xia, Phosphorus accumulation by bacteria isolated from a continuous-flow two-sludge system, Journal of Environmental Sciences, 19 (2007) 391-395.

[27] L. Deng, W. Guo, H.H. Ngo, X. Zhang, X.C. Wang, Q. Zhang, R. Chen, New functional biocarriers for enhancing the performance of a hybrid moving bed biofilm reactorâ€"membrane bioreactor system, Bioresource Technology, 208 (2016) 87-93.

[28] N.C. Nguyen, S.-S. Chen, H.T. Nguyen, H.H. Ngo, W. Guo, C.W. Hao, P.-H. Lin, Applicability of a novel osmotic membrane bioreactor using a specific draw solution in wastewater treatment, Science of The Total Environment, 518 â€“519 (2015) 586-594. 
[29] F. Li, Q. Cheng, Q. Tian, B. Yang, Q. Chen, Biofouling behavior and performance of forward osmosis membranes with bioinspired surface modification in osmotic membrane bioreactor, Bioresource Technology, 211 (2016) 751-758.

[30] B. Mi, M. Elimelech, Chemical and physical aspects of organic fouling of forward osmosis membranes, Journal of Membrane Science, 320 (2008) 292-302.

[31] E.R. Cornelissen, D. Harmsen, E.F. Beerendonk, J.J. Qin, K.F. de Korte, J.W.M.N. Kappelhof, The innovative Osmotic Membrane Bioreactor (OMBR) for reuse of wastewater, Water Science \& Technology, 63 (2011) 1557-1565.

[32] D. Xiao, C.Y. Tang, J. Zhang, W.C.L. Lay, R. Wang, A.G. Fane, Modeling salt accumulation in osmotic membrane bioreactors: Implications for FO membrane selection and system operation, Journal of Membrane Science, 366 (2011) 314-324.

[33] H.C. Duong, P. Cooper, B. Nelemans, T.Y. Cath, L.D. Nghiem, Optimising thermal efficiency of direct contact membrane distillation by brine recycling for small-scale seawater desalination, Desalination, 374 (2015b) 1-9.

[34] K.Y. Wang, M.M. Teoh, A. Nugroho, T.-S. Chung, Integrated forward osmosisâ€"membrane distillation (FOâ€"MD) hybrid system for the concentration of protein solutions, Chemical Engineering Science, 66 (2011) 2421-2430.

[35] H.C. Duong, A.R. Chivas, B. Nelemans, M. Duke, S. Gray, T.Y. Cath, L.D.

Nghiem, Treatment of RO brine from CSG produced water by spiral-wound air gap membrane distillation â€” A pilot study, Desalination, 366 (2015) 121-129. 


\section{Figure Captions}

Figure 1. Schematic of the laboratory-scale sponge biocarrier-OsMBR/MD system.

Figure 2. Acclimation of the sponge in the bioreactor with time using salt-tolerant microorganisms.

Figure 3. Laboratory-scale MD system for draw solution recovery.

Figure 4. Removal of (a) DOC and (b) $\mathrm{PO}_{4}{ }^{3-}-\mathrm{P}$ during moving sponge biocarrier-OsMBR operation. Operating conditions: draw solution $=\mathrm{MgCl}_{2}$, draw solution osmotic pressure $=75$ bar; feed solution $=$ synthetic high-salinity wastewater $(17 \mathrm{~g} \mathrm{NaCl} / \mathrm{L})$; flow rate of draw solution $=500 \mathrm{~mL} / \mathrm{min}$; membrane orientation $=$ active layer facing the feed solution.

Figure 5. Removal of (a) $\mathrm{NH}_{4}{ }^{+}-\mathrm{N}$, (b) $\mathrm{NO}_{2}{ }^{-}-\mathrm{N}$ and (c) $\mathrm{NO}_{3}{ }^{-}-\mathrm{N}$ during moving sponge biocarrierOsMBR operation. Operating conditions: draw solution $=\mathrm{MgCl}_{2}$, draw solution osmotic pressure $=75$ bar; feed solution $=$ synthetic high-salinity wastewater $(17 \mathrm{~g} \mathrm{NaCl} / \mathrm{L})$; flow rate of draw solution $=500 \mathrm{~mL} / \mathrm{min}$; membrane orientation $=$ active layer facing the feed solution.

Figure 6. (a) Water flux of the moveing sponge biocarrier-OsMBR system vs time; (b) Microbial community attached to the sponge carrier and FO membrane; (c) Variations of salt accumulation during sponge biocarrier-OsMBR operation. Operating conditions: draw solution $=\mathrm{MgCl}_{2}$; draw solution osmotic pressure $=75$ bar; feed solution $=$ synthetic high-salinity wastewater $(17 \mathrm{~g} \mathrm{NaCl} / \mathrm{L})$; flow rate of draw solution $=500 \mathrm{~mL} / \mathrm{min}$; membrane orientation $=$ active layer facing the feed solution.

Figure 7. Water flux, salt rejection, and feed conductivity in the MD process as a function of time. Operating conditions: diluted $\mathrm{MgCl}_{2}$ draw solution as feed; $\mathrm{T}_{\text {feed }}=55^{\circ} \mathrm{C} ; \mathrm{T}_{\text {distillate }}=20{ }^{\circ} \mathrm{C}$; distillate flow rate $=1.5 \mathrm{~L} / \mathrm{min}$; PTFE MD membrane pore size $=0.45 \mu \mathrm{m}$. Error bars are based on the standard deviations of three replicate tests. 


\section{Tables}

Table 1. Characteristics of the MD and FO membranes

\begin{tabular}{|c|c|c|c|c|}
\hline Membrane & Thickness & $\begin{array}{l}\text { Mean pore } \\
\text { size }\end{array}$ & Contact angle $^{\circ}$ & $\begin{array}{l}\text { Effective area per } \\
\text { module }\end{array}$ \\
\hline PTFE MD & $160 \mu \mathrm{m}$ & $0.45 \mu \mathrm{m}$ & $118^{\circ}$ & $100 \mathrm{~cm}^{2}$ \\
\hline CTA-NW FO & $50 \mu \mathrm{m}$ & $0.37 \mathrm{~nm}$ & $66^{\circ}$ & $130 \mathrm{~cm}^{2}$ \\
\hline
\end{tabular}


Figures

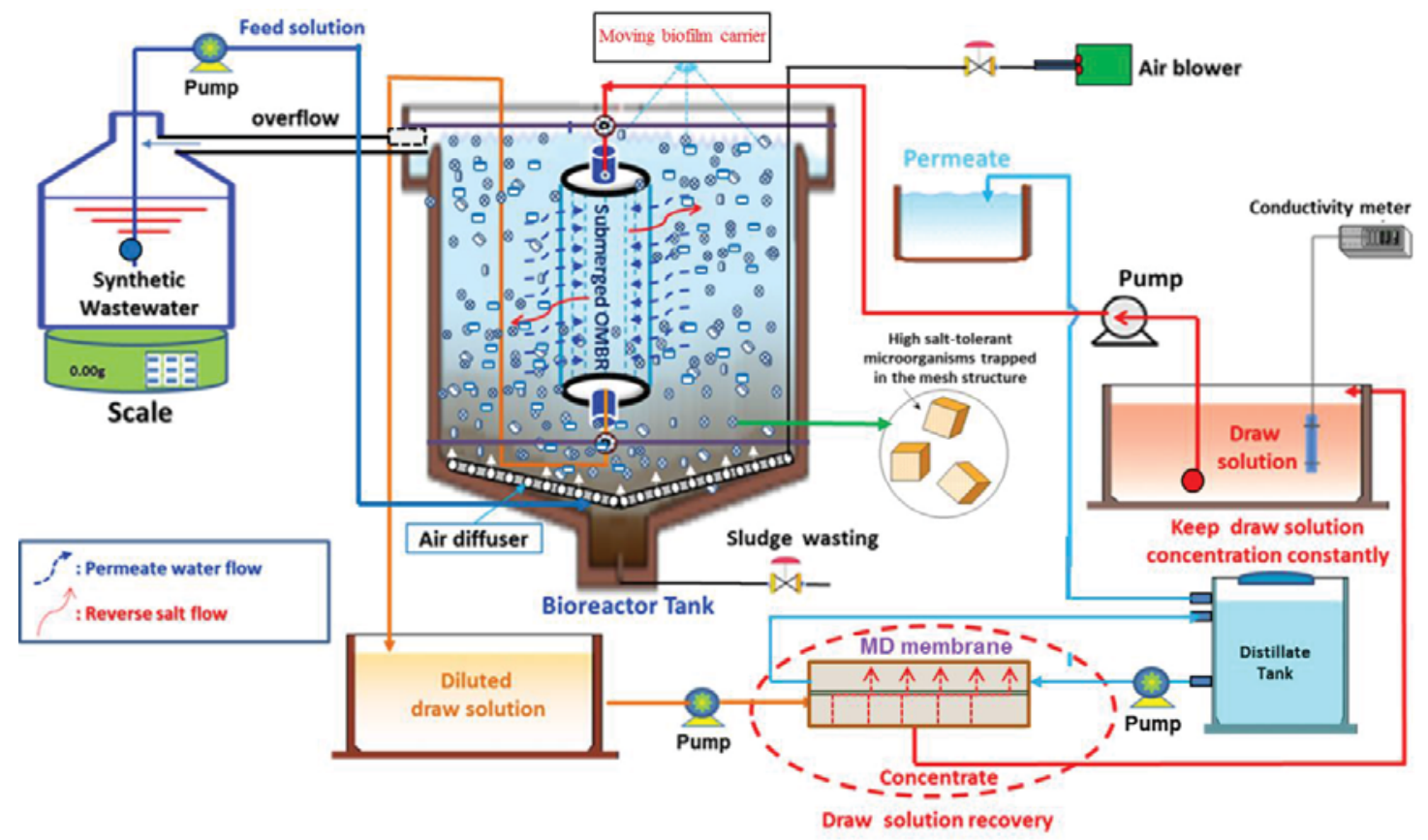

Figure 1. Schematic of the laboratory-scale sponge biocarrier-OsMBR/MD system. 


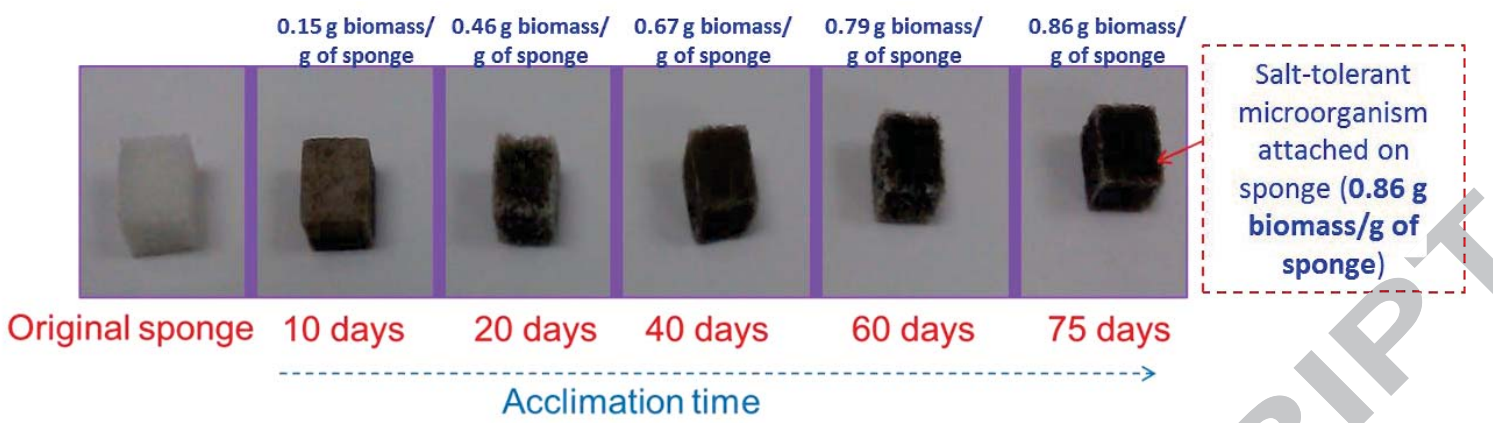

Figure 2. Acclimation of the sponge in the bioreactor with time using salt-tolerant microorganisms. 


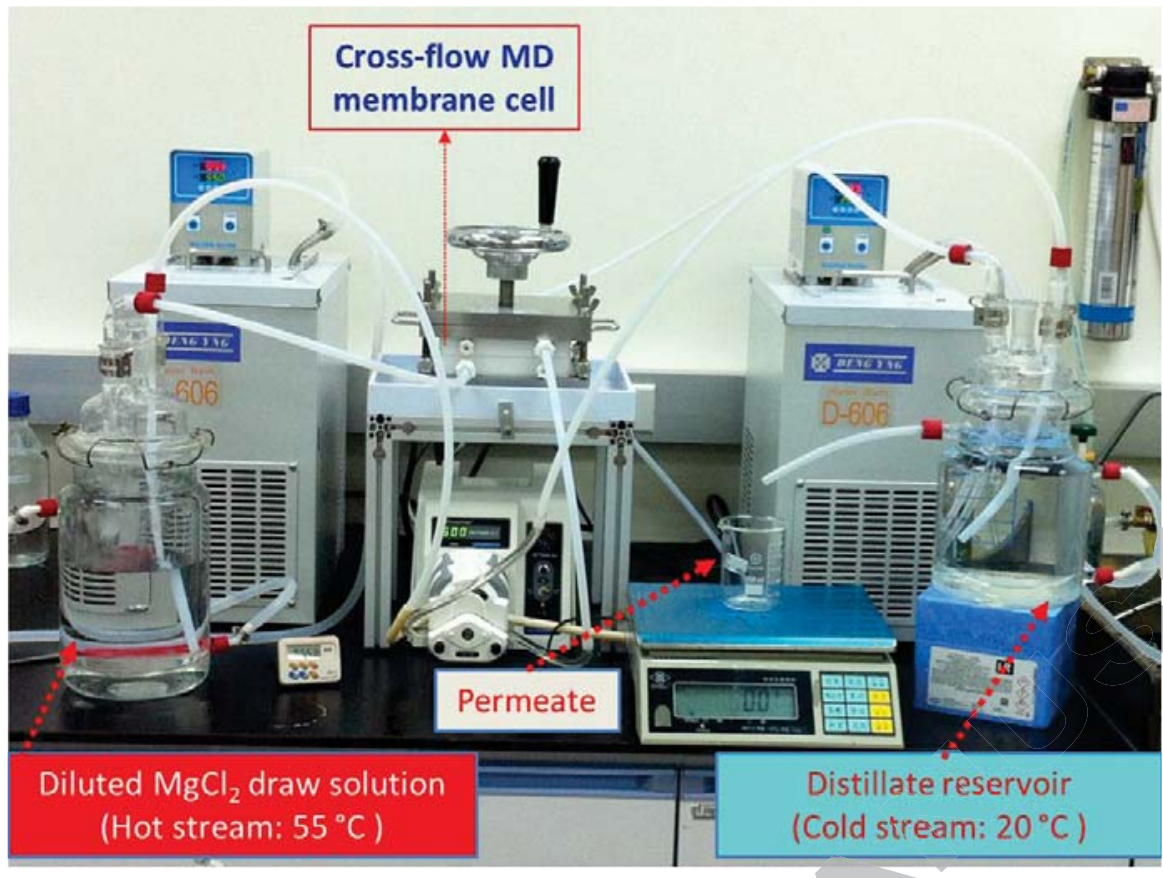

Figure 3. Laboratory-scale MD system for draw solution recovery. 

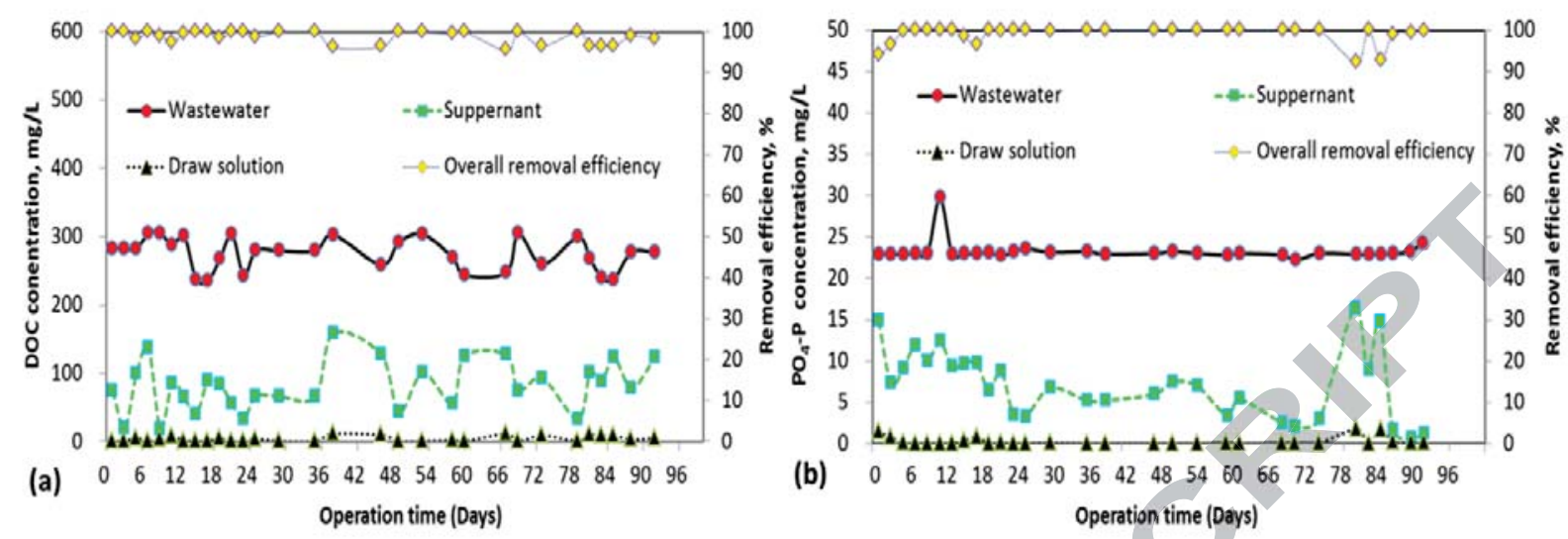

Figure 4. Removal of (a) DOC, (b) $\mathrm{PO}_{4}{ }^{3-}-\mathrm{P}$ during moving sponge biocarrier-OsMBR operation. Operating conditions: draw solution $=\mathrm{MgCl}_{2}$, draw solution osmotic pressure $=75$ bar; feed solution $=$ synthetic high-salinity wastewater $(17 \mathrm{~g} \mathrm{NaCl} / \mathrm{L})$; flow rate of draw solution $=500$ $\mathrm{mL} / \mathrm{min}$; membrane orientation $=$ active layer facing the feed solution. 


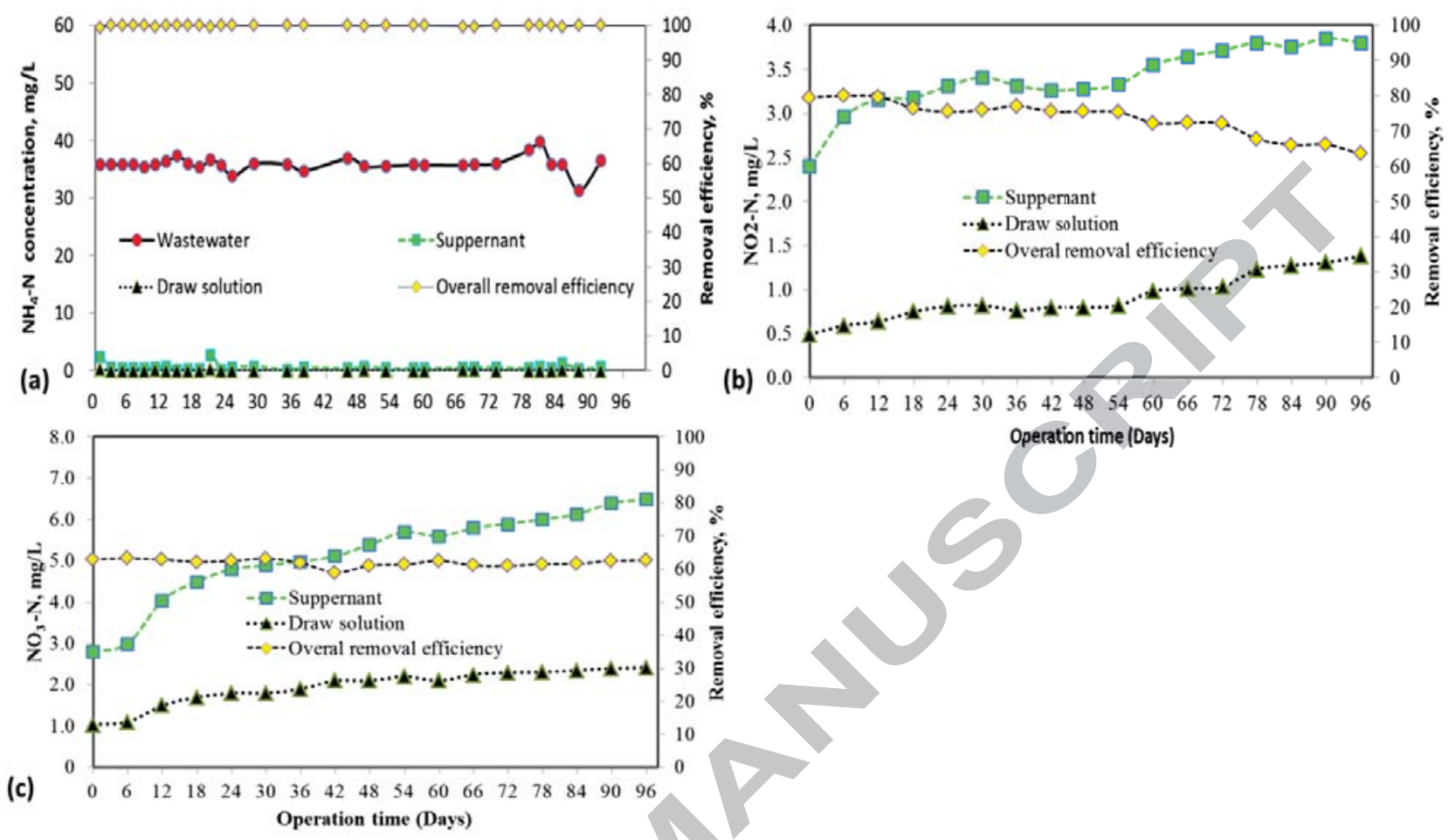

Figure 5. Removal of (a) $\mathrm{NH}_{4}{ }^{+}-\mathrm{N}$, (b) $\mathrm{NO}_{2}-\mathrm{N}$ and (c) $\mathrm{NO}_{3}{ }^{-}-\mathrm{N}$ during moving sponge biocarrierOsMBR operation. Operating conditions: draw solution $=\mathrm{MgCl}_{2}$, draw solution osmotic pressure $=75$ bar; feed solution $=$ synthetic high-salinity wastewater $(17 \mathrm{~g} \mathrm{NaCl} / \mathrm{L})$; flow rate of draw solution $=500 \mathrm{~mL} / \mathrm{min}$; membrane orientation $=$ active layer facing the feed solution . 

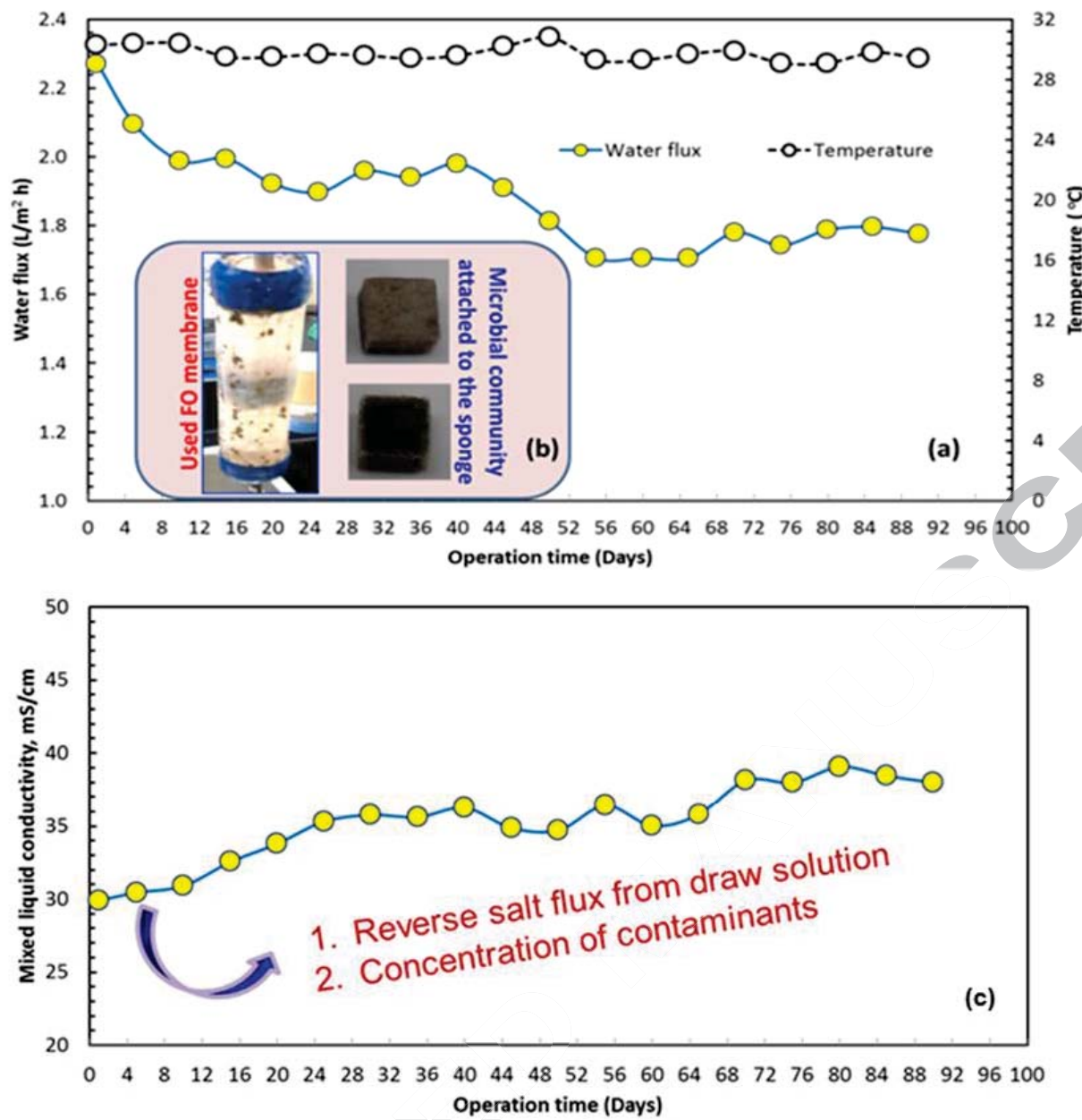

Figure 6. (a) Water flux of the moveing sponge biocarrier-OsMBR system vs time; (b) Microbial community attached to the sponge carrier and FO membrane; (c) Variations of salt accumulation during sponge biocarrier-OsMBR operation. Operating conditions: draw solution $=\mathrm{MgCl}_{2}$; draw solution osmotic pressure $=75 \mathrm{bar}$; feed solution = synthetic high-salinity wastewater $(17 \mathrm{~g} \mathrm{NaCl} / \mathrm{L})$; flow rate of draw solution $=500 \mathrm{~mL} / \mathrm{min}$; membrane orientation $=$ active layer facing the feed solution. 


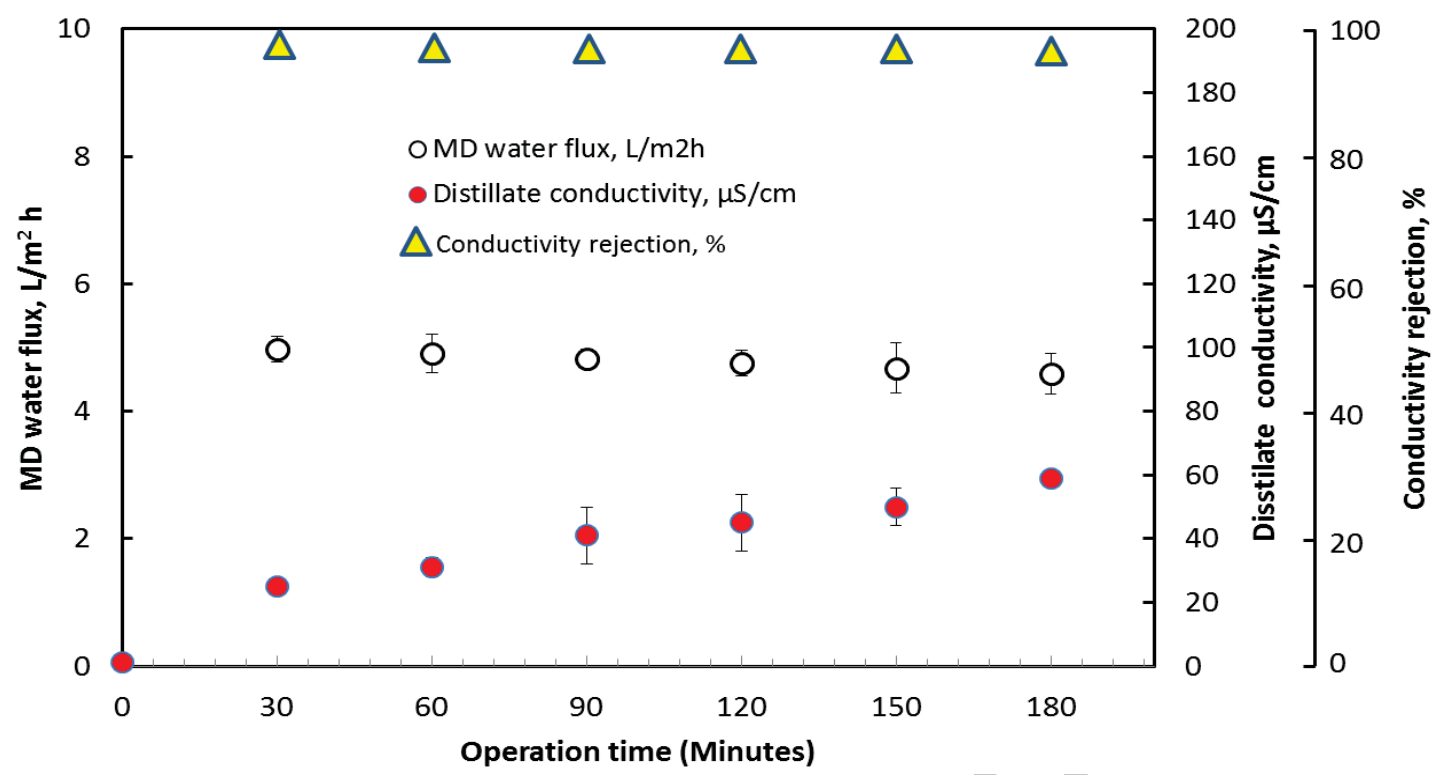

Figure 7. Water flux, salt rejection, and feed conductivity in the MD process as a function of time. Operating conditions: diluted $\mathrm{MgCl}_{2}$ draw solution as feed; $\mathrm{T}_{\text {feed }}=55^{\circ} \mathrm{C} ; \mathrm{T}_{\text {distillate }}=20{ }^{\circ} \mathrm{C}$; distillate flow rate $=1.5 \mathrm{~L} / \mathrm{min}$; PTFE MD membrane pore size $=0.45 \mu \mathrm{m}$. Error bars are based on the standard deviations of three replicate tests. 


\section{Highlights:}

- Successful design of a novel moving sponge biocarrier-OsMBR/MD system.

- Water flux declined due to salinity buildup in the bioreactor.

- The moving sponge in the bioreactor contributed considerably to reduced FO membrane fouling.

- Salt-tolerant microorganisms could work efficiently in salt concentrations of $2.4 \%$.

- A PTFE MD membrane achieved high draw solution recovery with 99.9\% salt rejection. 